\title{
Chloroplast and nuclear DNA studies in Iberian Peninsula endemic Silene scabriflora subspecies using cPSSR and ISSR markers: Genetic diversity and phylogenetic relationships
}

\author{
Vanessa Ferreira ${ }^{\text {a, * }}$, Isaura Castro b, c , João Rocha ${ }^{\mathrm{d}}$, António L. Crespí ${ }^{\mathrm{e}}$, \\ Olinda Pinto-Carnide ${ }^{\mathrm{a}}$, Francisco Amich ${ }^{\mathrm{f}}$, Rubim Almeida ${ }^{\mathrm{d}}$, \\ Valdemar Carnide ${ }^{\text {b, } c}$ \\ a University of Trás-os-Montes and Alto Douro, 5000-801 Vila Real, Portugal \\ b Department of Genetics and Biotechnology, University of Trás-os-Montes and Alto Douro, 5000-801 Vila Real, Portugal \\ ${ }^{\mathrm{c}}$ Centre for the Research and Technology of Agro-Environmental and Biological Sciences (CITAB), University of Trás-os-Montes and Alto \\ Douro, 5000-801 Vila Real, Portugal \\ d Department of Biology, CIBIO - Faculty of Sciences, University of Porto, 4169-007 Porto, Portugal \\ e Department of Biology and Environment - CITAB, Botanical Garden and Herbarium, University of Trás-os-Montes and Alto Douro, \\ 5000-801 Vila Real, Portugal \\ ${ }^{\mathrm{f}}$ Evolution, Taxonomy and Conservation Group (ECOMED), Department of Botany, University of Salamanca, E-37008 Salamanca, Spain
}

\section{A R T I C L E I N F O}

\section{Article history:}

Received 16 December 2014

Received in revised form 18 June 2015

Accepted 27 June 2015

Available online $\mathrm{xxx}$

\section{Keywords:}

Silene scabriflora

Molecular markers

Genetic differentiation

Geographic variation

Refugia

\begin{abstract}
A B S T R A C T
The Iberian Peninsula is considered to be a center of natural distribution and diversity for several species of flora. In this study, the genetic diversity and phylogenetic relationships of Silene scabriflora from the Iberian Peninsula were analyzed using ISSR and cPSSR markers. A total of 161 ISSR markers were produced, with a percentage of polymorphic loci of 99.4\%. A high level of genetic differentiation among S. scabriflora subspecies (S. scabriflora spp. scabriflora, S. scabriflora spp. megacalycina, S. scabriflora spp. gallaecica and $S$. scabriflora spp. tuberculata) was observed $(\mathrm{Gst}=0.3685)$, which was illustrated by UPGMA dendrogram. Molecular results are in agreement with subspecies morphological characterization, particularly supporting the morphological similarities between $S$. scabriflora spp. scabriflora and S. scabriflora spp. megacalycina. Three of the five cPSSR loci analyzed were polymorphic and the two different alleles found in each polymorphic locus were combined in two different haplotypes. The results obtained in this study provide evidences for a long distance dispersion theory, Southern of Spain as the biodiversity center of $S$. scabriflora; for speciation, Southern of Spain as a refugia-within-refugia considering the speciation that occurs in S. scabriflora spp. scabriflora found in this region and the possibility of S. scabriflora spp. scabriflora as being ancestral of the species.
\end{abstract}

(c) 2015 Elsevier Ltd. All rights reserved.

\section{Introduction}

The genus Silene belongs to the Caryophyllaceae family and has been recognized since the early days of evolutionary biology as an important model system in ecology and evolution with remarkably interesting features for studying sexual and

\footnotetext{
* Corresponding author.

E-mail address: vanessa.cm.ferreira29@gmail.com (V. Ferreira).
} 
mating systems (Bernasconi et al., 2009). This genus comprises about 23 sections and 700 species worldwide, 194 of which are reported to be present in Europe (Bratteler et al., 2006).

The variety of ecological habitats of Silene distribution in the Mediterranean region of Eastern Europe and their strong differentiation makes this region a natural global centre of this genus and a site for diversity.

The Iberian Peninsula is described as one of the most important Pleistocene glacial refugia in the European subcontinent (Hewitt, 2000, 1999) and the high level of endemism in Iberian plants and animals (Doadrio, 1988; Garcia-Barros et al., 2002; Gómez-Campo et al., 1984; Moreno Saiz et al., 1998; Ribera, 2000) indirectly suggest in situ long-term survival, differentiation and speciation in this area.

Silene scabriflora Brot. is an endemic species of the Iberian Peninsula and includes four subspecies, Silene scabriflora spp. scabriflora, Silene scabriflora spp. tuberculata (Ball) Talavera, Silene scabriflora spp. megacalycina Talavera and Silene scabriflora spp. gallaecica Talavera.

S. scabriflora spp. scabriflora is the most widespread subspecies throughout the Iberian Peninsula, although absent in the northwestern (NW) region. The remaining three subspecies are narrowly endemic, with more restricted distribution. $S$. scabriflora spp. megacalycina is confined to the Spanish provinces of León, Lugo and Ourense in the NW Iberian Peninsula. S. scabriflora spp. gallaecica is also endemic to the NW of Iberian Peninsula and is restricted to the Atlantic coast (La Coruña and Pontevedra provinces). S. scabriflora spp. tuberculata mainly appears in the southern part of the Iberian Peninsula, in the Portuguese Algarve and in the Spanish provinces of Cádiz, Granada, Malaga and Seville and with sporadic occurrences in NW Morocco.

These four subspecies are currently recognized as independent subspecies by the Spanish Flora book (Talavera, 1991). However, this classification is based only on morphological characters which are very similar between some of them: $S$. scabriflora spp. scabriflora, S. scabriflora spp. megacalycina and S. scabriflora spp. tuberculata, differ only in a few morphological characters. To date, no systematic studies are available and more detailed studies are important for providing new insights into the phylogenetic relationship between these S. scabriflora subspecies.

Different types of molecular markers have been successfully used in phylogenetics, systematic, evolutionary and conservation biology and molecular ecology. Nuclear inter-simple sequence repeats (ISSR) are a powerful tool for investigating genetic variation within species (Coutinho et al., 2014; Mao and Fang, 2014; Zietkiewicz et al., 1994). However, these markers have limitations due to their biparental inheritance. In contrast, uniparental inherited organelle DNA markers, such as chloroplast simple sequence repeats (cpSSRs), allow overcoming this limitation and complement information given by nuclear markers. An important advantage of ISSR and cPSSR marker systems is that no knowledge of the target species' genome sequence is required for analyses (Wang et al., 2008).

The Iberian Peninsula has been described as a biodiversity hotspot (Arroyo, 1997; Medail and Quezel, 1997), and as a melting pot for plant biodiversity (Rodríguez-Sánchez et al., 2008). Although some reports on endemic Silene species are available, none of them include the Iberian Peninsula S. scabriflora subspecies. In the present study the S. scabriflora subspecies were analyzed by ISSRs and cpSSRs in order to for the first time, assess the genetic diversity of S. scabriflora (1), estimate the genetic differentiation and phylogenetic relationships among S. scabriflora subspecies (2) and understand possible glacial refugia of S. scabriflora subspecies on the Iberian Peninsula (3).

\section{Material and methods}

\subsection{Plant material and sampling}

Young intact leaves of 4-8 individual plants, sometimes the total number of plants found, of each S. scabriflora subspecies - Silene scabriflora spp. scabriflora, Silene scabriflora spp. megacalycina, Silene scabriflora spp. tuberculata and Silene scabriflora spp. gallaecica were collected in their natural habitat in the Iberian Peninsula, then immediately dried in silica gel and stored at $-80^{\circ} \mathrm{C}$ until DNA extraction. The distance between the plants sampled was at least $1 \mathrm{~m}$ in order to avoid collecting leaves from the same individual. S. scabriflora spp. scabriflora was collected in Southern Spain and Central Portugal (HVR 19519, HVR 20901); the remaining three subspecies have a more restricted distribution and so were collected only in the provinces where their specimens exist: S. scabriflora spp. tubeculata in Southern Spain (HVR 19578), S. scabriflora spp. megacalycina in NW Spain (HVR 20902; HVR20903) and S. scabriflora spp. gallaecica in NW Spain (HVR 19534, HVR 19565; HVR20904; HVR20905) Atlantic coast (Fig. 1). All these specimens are included in the HVR herbarium (http://sweetgum.nybg.org/ih/herbarium.php? irn=126327).

\subsection{DNA isolation}

Total DNA was extracted from $100 \mathrm{mg}$ of frozen leaf tissue following the protocol supplied in the DNeasy ${ }^{\circledR}$ Plant Mini Kit (QIAGEN, Düren, Germany). Extracted DNA was quantified by UV spectrometer (Nanodrop ${ }^{\circledR}$ ND-1000, Thermo Fisher Scientific, Waltham, MA, USA) followed by a quality check in $1.0 \%$ agarose gel electrophoresis and necessary dilutions were done (about $10 \mathrm{ng} / \mu \mathrm{L}$ ). 


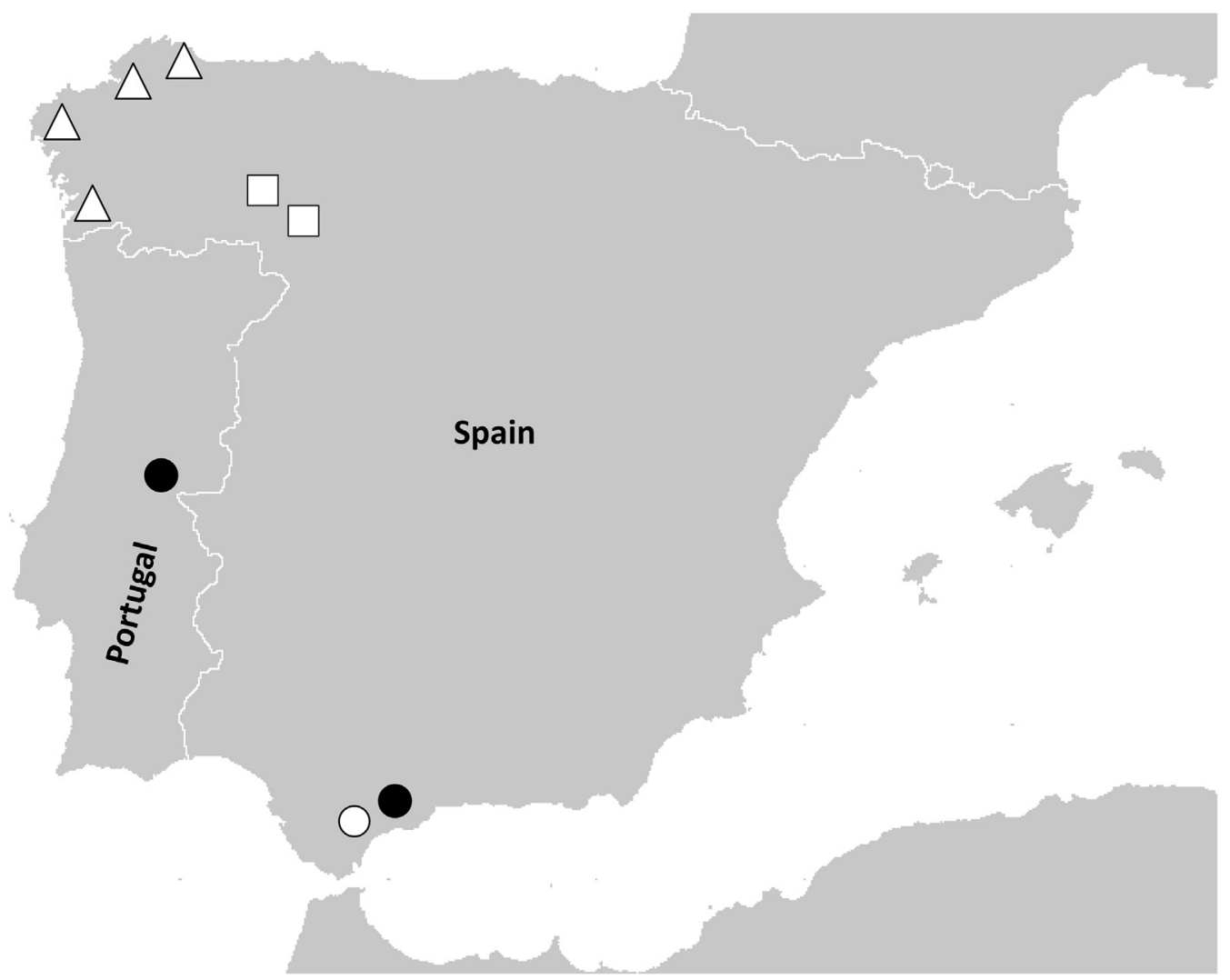

Fig. 1. Geographic location of S. scabriflora subspecies studied (white triangles - S. scabriflora spp. gallaecica; white squares - S. scabriflora spp. megacalycina; black circles - S. scabriflora spp. scabriflora; white circles - S. scabriflora spp. tuberculata).

\subsection{ISSR amplification}

After pre-screening 14 ISSR primers from the UBC\#100/9 set (University of British Columbia, Vancouver, BC, Canada) tested in DNA bulks from each subspecies, 10 primers were selected (UBC807, UBC811, UBC827, UBC835, UBC848, UBC853, UBC857, UBC886, UBC888 and UBC889) for further analysis, which combined high polymorphism with clear and reproducible fragments ( $\geq 2$ replications).

Each amplification for ISSR primers was performed in a reaction volume of $20.0 \mu \mathrm{L}$ containing $10 \mathrm{ng}$ of genomic DNA, $0.5 \mu \mathrm{M}$ of primer, $10 \mathrm{mM}$ of dNTPs, $25 \mathrm{mM}$ of $\mathrm{MgCl}_{2}$ and $1.0 \mathrm{U}$ of Taq DNA polimerase in the manufacture's buffer (Thermo Fisher Scientific, Waltham, MA, USA).

The ISSR-PCR reactions were carried out using the T-Professional Basic thermocycler (Biometra, Germany). After an initial denaturation of $5 \mathrm{~min}$ at $94{ }^{\circ} \mathrm{C}, 45$ cycles for $30 \mathrm{~s}$ at $94{ }^{\circ} \mathrm{C}, 45 \mathrm{~s}$ at $52{ }^{\circ} \mathrm{C}, 2 \mathrm{~min}$ at $72{ }^{\circ} \mathrm{C}$ were performed, followed by a final 10 min extension at $72{ }^{\circ} \mathrm{C}$. PCR products were separated in $1.8 \%(\mathrm{p} / \mathrm{v})$ agarose gels using TBE buffer, stained with ethidium bromide, and the molecular weights were estimated using the GeneRulerTM 100 bp DNA Ladder Plus (Thermo Fisher Scientific, Waltham, MA, USA). The electrophoretic patterns of the PCR products were digitally recorded using a Molecular Image Gel-Doc ${ }^{\mathrm{TM}} \mathrm{XR}+$ with Image Lab ${ }^{\mathrm{TM}}$ Software (BIO RAD, Hercules, CA, USA). The images were analysed using the same software, which assigns a fragment size to each band using an algorithm based on the $100 \mathrm{bp}$ ladder. These fragment sizes were used to assign loci for each primer.

\section{4. cPSSR amplification}

Five chloroplast SSR loci (ccmp3, ccmp4, ccmp6, ccmp7 and ccmp10), were amplified in all samples using the consensus primer pairs designed by Weising and Gardner (1999). The forward primer of each pair was fluorescently labeled with 6-FAM (ccmp3 and ccmp4), HEX (ccmp6) or NED (ccmp7 and ccmp10). PCR reactions were performed in a $20 \mu \mathrm{L}$ final volume containing $10 \mathrm{ng}$ of template DNA, $0.15 \mathrm{mM}$ of each dNTP, $1 \mathrm{U} \mathrm{FIREpol}^{\mathbb{B}}$ DNA polymerase in the manufacturer's buffer (Solis BioDyne, Estonia), $2 \mathrm{mM} \mathrm{MgCl}$ and $0.4 \mu \mathrm{M}$ of forward and reverse primers. Amplifications were carried out in a T-Professional Basic thermocycler (Biometra, Germany) initially set for $3 \mathrm{~min}$ at $94{ }^{\circ} \mathrm{C}$, followed by 30 cycles of $94{ }^{\circ} \mathrm{C}$ for $45 \mathrm{~s}, 50^{\circ} \mathrm{C}(\mathrm{ccmp} 4$, 
ccmp6, ccmp7 and ccmp10) or $55{ }^{\circ} \mathrm{C}(\mathrm{ccmp} 3)$ for $45 \mathrm{~s}$, and $72{ }^{\circ} \mathrm{C}$ for $1 \mathrm{~min}$, with a final extension at $72{ }^{\circ} \mathrm{C}$ for $5 \mathrm{~min}$. PCR products were visualized by electrophoresis on $2.5 \%$ agarose gels $(\mathrm{p} / \mathrm{v})$, followed by ethidium bromide staining.

Amplified products were run on the ABI Prism ${ }^{\circledR} 3730$ Genetic Analyzer using the GeneScan ${ }^{\mathrm{TM}} 500$ LIZ $^{\circledR}$ size standard (PE Applied Biosystems, Foster City, CA, USA).

\subsection{Data analysis}

For the genetic similarity analysis, ISSR DNA bands were scored as present (1) or absent ( 0 ) on the basis of size comparison with an external standard (GeneRulerTM 100 bp DNA Ladder Plus) (Thermo Fisher Scientific, Waltham, MA, USA) to produce a set of binary data. Due to dominancy of these markers, it was assumed that each DNA fragment position corresponds to a locus with two alleles revealed by band absence or presence (Powell et al., 1996). Only data from intensely stained, unambiguous, clear and reproducible bands ( $\geq 2$ replications) were scored and used for statistical analysis.

The resulting binary data matrix of ISSR was analyzed using POPGENE version 32 (Yeh et al., 2000) to estimate genetic diversity parameters assuming Hardy-Weinberg equilibrium: the number (NPL) and percentage of polymorphic loci (\%PL) were measured at species level. Likewise, genetic diversity was determined according to Nei (1973) and calculated at two levels: total genetic diversity within S. scabriflora subspecies as a whole (h) and genetic diversity among subspecies (Hs). The coefficient of genetic differentiation (Gst) (Nei, 1973) and Shannon information index (I) (Lewontin, 1972) were also estimated.

Based on the same data, a dendrogram was constructed by cluster analysis using the Unweighted Pair Group Method of the Arithmetic Averages (UPGMA) using the Simple Matching Coefficient (SM) as implemented in the software package NTSYSpc, version 2.02g (Rohlf, 2008).

Labeled products of cPSSRs were analysed and sized by means of Peak Scanner ${ }^{\mathrm{TM}}$ v1.0 free software (PE Applied Biosystems, Foster City, CA, USA).

\section{Results and discussion}

This is the first study concerning S. scabriflora genetic diversity and differentiation. S. scabriflora spp. scabriflora is widespread on the Iberian Peninsula. However, the remaining three subspecies are scarce with a very narrow distribution, and are currently restricted to a few specific provinces of the Iberian Peninsula.

The greater the genetic diversity of a species is, the more complex is its genetic background, the stronger its evolutionary potential and ability to withstand adversity and the more easily it will expand its distribution range and adapt to new environments. Therefore, research on the genetic diversity within a species is fundamental to understanding its origin and evolution (Zhao et al., 2014).

In this study, unambiguous, reproducible and polymorphic ISSR patterns were obtained using ten selected primers. A total of 161 markers were scored, which 160 were polymorphic among the four S. scabriflora subspecies (Table 1) and 17 subspecies-specific. UBC835 and UBC853 primers produced the largest number of markers - 22 and 21, respectively. Analysis of the data showed that the percentage of polymorphic loci (\% $\%$ r) ranged from $85.7 \%$ to $100 \%$, with a mean value of $99.4 \%$ (Table 1). These data reveal that ISSR markers are highly polymorphic, permitting a deduction about the genetic diversity of $S$. scabriflora species and estimate of the genetic relationship between S. scabriflora subspecies.

The genetic diversity of $S$. scabriflora species was assessed by Nei's gene diversity coefficient (Nei, 1973) and was performed at two levels; total genetic diversity of S. scabriflora subspecies as a whole (h) and genetic diversity among S. scabriflora subspecies (Hs), with values of 0.2831 and 0.1788 , respectively. Shannon's diversity index (I) (Lewontin, 1972) was determined, being 0.4451. This level of genetic diversity has also been observed in other species using ISSR markers, namely Tuberaria major $(\mathrm{h}=0.197, \mathrm{I}=0.324$, \% $\mathrm{PL}=97.7)$ (Trindade et al., 2012) and Plantago algarbiensis $(\mathrm{h}=0.2309 ; \mathrm{I}=0.3520 ; \%$ $\mathrm{PL}=83.1$ ) (Ferreira et al., 2013), both of which are restricted to the southern Iberian Peninsula.

Table 1

DNA profile and polymorphism in S. scabriflora using 10 ISSR primers (TL - Total Loci; PL - Polymorphic Loci; EL - Exclusive Loci; \%PL - Percentage of polymorphic Loci).

\begin{tabular}{|c|c|c|c|c|c|c|}
\hline & Primer sequence $\left(5^{\prime}-3^{\prime}\right)$ & $\mathrm{TL}$ & PL & ML & EL & $\% \mathrm{PL}$ \\
\hline UBC807 & $(\mathrm{AG})_{8} \mathrm{~T}$ & 16 & 16 & 0 & 0 & 100.00 \\
\hline UBC811 & $(\mathrm{GA})_{8} \mathrm{C}$ & 14 & 14 & 0 & 0 & 100.00 \\
\hline UBC827 & $(\mathrm{AC})_{8} \mathrm{G}$ & 13 & 13 & 0 & 0 & 100.00 \\
\hline UBC835 & $(\mathrm{AG})_{8} \mathrm{YC}$ & 22 & 22 & 0 & 1 & 100.00 \\
\hline UBC848 & $(\mathrm{CA})_{8} \mathrm{RG}$ & 17 & 17 & 0 & 0 & 100.00 \\
\hline UBC853 & $(\mathrm{TC})_{8} \mathrm{RT}$ & 21 & 21 & 0 & 0 & 100.00 \\
\hline UBC857 & $(\mathrm{AC})_{8} \mathrm{YG}$ & 19 & 19 & 0 & 0 & 100.00 \\
\hline UBC886 & $\operatorname{VDV}(C T)_{7}$ & 14 & 14 & 0 & 0 & 100.00 \\
\hline UBC888 & $\mathrm{BDB}(\mathrm{CA})_{7}$ & 18 & 18 & 0 & 0 & 100.00 \\
\hline UBC889 & $\mathrm{DBD}(\mathrm{AC})_{7}$ & 7 & 6 & 1 & 0 & 85.7 \\
\hline Total & & 161 & 160 & 1 & 1 & 99.4 \\
\hline
\end{tabular}


The great number of endemic species in this region may be due to the Iberian Peninsula having been important Pleistocene glacial refugia. Due to the dramatic climatic changes, this period caused considerable migration, fragmentation and extinction of populations (Bennett, 1996; Comes and Kadereit, 1998; Dynesius and Jansson, 2000), and Southern Europe maintained a great genetic diversity. In this refugia region there was a tendency for higher accumulation of genetic diversity with persistence and relative stability. The varied topography of the mountains in the southern refugia may have split a species range into isolated disjuncts (with restricted gene flow) that over time diverged and differentiated into unique genetic variants with distinct features (Hewitt, 1999). Populations in the South may also have survived glacial cycles by ascending the mountains during warm interglacial periods and descending during the cold glacial periods. Moreover, the Iberian Peninsula physiographic complexity and geographical position favored survival throughout the region in the Pleistocene, leading to the emergence of several endemic species.

The Gst is a widely used statistical measure of genetic differentiation. It is not affected by the reproductive system of a species, by the number of alleles per locus or by the effect of evolutionary pressures. The genetic differentiation (Gst) among $S$. scabriflora subspecies was 0.3685 , a value which is considered high and supports the idea of a fragmented refugia structure in the past. This value was reflected in the dendrogram based on the genetic similarity obtained using the SM coefficient since the four subspecies are differentiated into two main clusters (Fig. 2). The SM coefficient is considered the more appropriate coefficient of similarity for dominant markers when considering closely related taxa (Halldén et al., 1994). Cluster analyses places the plants into groups on a hierarchical structure: the maximal similarity for plants belonging to the same group and minimal for plants sorted in different groups (Laurentin, 2009). Cluster I in the dendrogram comprises three of the four subspecies, S. scabriflora spp. scabriflora, S. scabriflora spp. megacalycina and S. scabriflora spp. tuberculata, and cluster II only S. scabriflora spp. gallaecica. The coefficient of similarity (0.46) between them indicates a considerable differentiation level regarding an analysis at subspecies level (Fig. 2). Cluster I is further divided into two subgroups, with a coefficient of similarity of 0.58 (Fig. 2). Subgroup Ia) includes S. scabriflora spp. scabriflora and S. scabriflora spp. megacalycina with a coefficient of similarity of 0.70 and subgroup Ib) S. scabriflora spp. tuberculata (Fig. 2). This clustering analysis of S. scabriflora subspecies by ISSR markers was in agreement with their morphological traits described in Flora Ibérica, particularly supporting the morphologic similarities between S. scabriflora spp. scabriflora and S. scabriflora spp. megacalycina.

Certain patterns of genetic and phenotypic differentiation across a species' geographic distribution can be attributed to local adaptation, which is expected to increase quantitative genetic differentiation at phenotypic traits above the range of genetic differentiation values obtained at neutral marker loci (Pujol et al., 2008; Whitlock, 2008). The overlapping of S. scabriflora spp. scabriflora and S. scabriflora spp. megacalycina distributions can explain their genetic and morphological similarities.

Summing up, S. scabriflora spp. scabriflora and S. scabriflora spp. megacalycina are more closely related and S. scabriflora spp. tuberculata and, particularly, S. scabriflora spp. gallaecica are more distant (Fig. 2). These latter two subspecies are located closer to the sea; the Mediterranean and Atlantic coasts, respectively, and are influenced by very specific and characteristic environments which can partially explain their divergence compared to the other two subspecies. These results suggest some sort of isolation by distance pattern that probably reflects a very ancient expansion which likely occurred during the Pleistocene. Another alternative explanation is that the Silene scabriflora subspecies distribution may have been affected by the

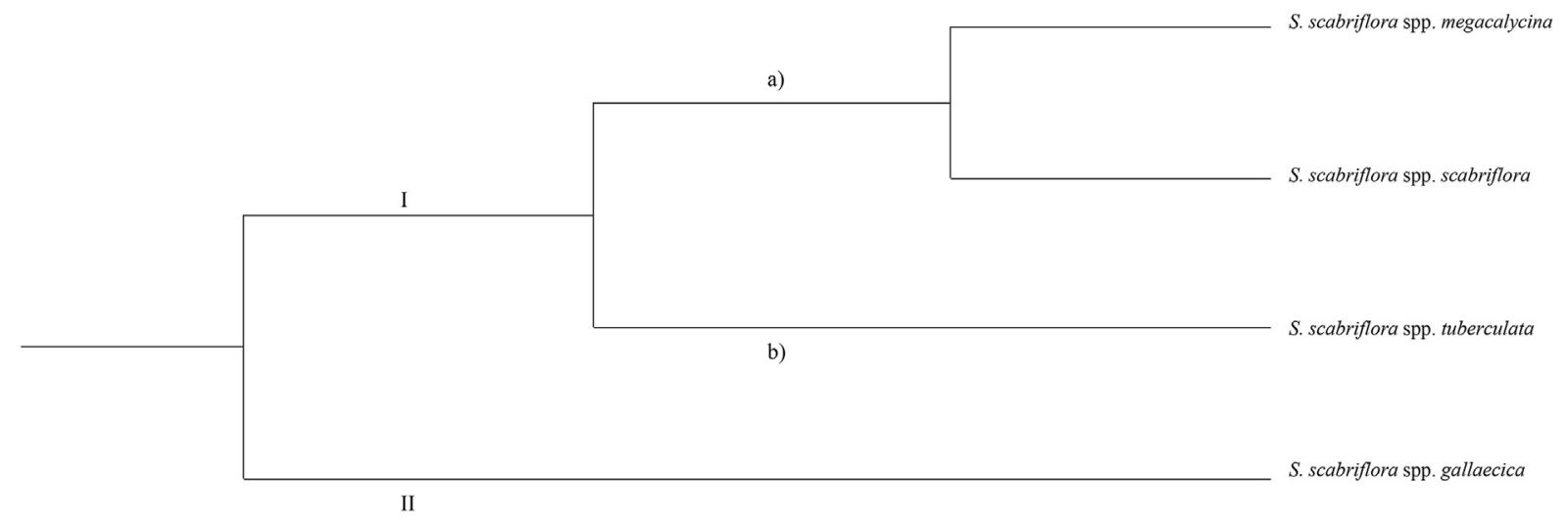

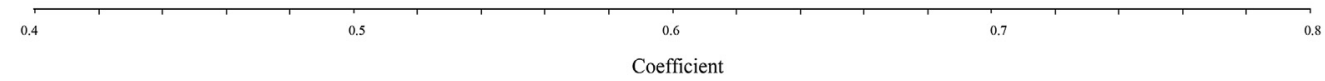

Fig. 2. Dendrogram of $S$. scabriflora subspecies showing genetic similarity, based on ISSR data, using the UPGMA method and SM coefficient. 
Table 2

Size of the alleles for the five cPSSR loci analyzed in S. scabriflora subspecies and their haplotypes.

\begin{tabular}{|c|c|c|c|c|c|c|}
\hline Subspecies & ccmp3 (bp) & ccmp4 (bp) & ccmp6 (bp) & ccmp7 (bp) & ccmp10 (bp) & cpSSR haplotype \\
\hline S. scabriflora spp. megacalycina & 101 & 112 & 109 & 136 & 88 & I \\
\hline \multirow[t]{2}{*}{ S. scabriflora spp. scabriflora } & 101 & 112 & 109 & 136 & 88 & I \\
\hline & 101 & 113 & 100 & 136 & 87 & II \\
\hline S. scabriflora spp. tuberculata & 101 & 112 & 109 & 136 & 88 & I \\
\hline S. scabriflora spp. gallaecica & 101 & 112 & 109 & 136 & 88 & I \\
\hline
\end{tabular}

particular conditions of one much overlooked period when studying recolonization - the Mid-holocene period which occurred after the last glacial maximum and is described by summers up to five degrees warmer but with colder winters.

An objective of this study was to identify possible glacial refugia of Silene scabriflora subspecies in the Iberian Peninsula. ISSR markers, despite being a suitable molecular marker to assess genetic diversity since it amplifies many different regions of a genome and is simple, reproducible and cost-effective, as a nuclear dominant marker, it doesn't allow for reconstruction of colonization patterns (Bellucci et al., 2011; Wang et al., 2008, 2011). For this reason, and in order to explore exchanges between refugia in S. scabriflora species, chloroplast SSR markers were also performed.

From the set of $10 \mathrm{ccmp}$ pairs designed by Weising and Gardner (1999) to amplify cpSSR loci, ccmp3, ccmp4, ccmp6, ccmp7 and ccmp10 were chosen to amplify all of the $S$. scabriflora subspecies plants analyzed. Eight different alleles at the five loci amplified were detected (Table 2). Three loci (ccmp4, ccmp6 and ccmp10) out of the five chloroplast microsatellites screened were polymorphic, the remaining two loci (ccmp3 and ccmp7) being monomorphic in all of S. scabriflora subspecies plants analyzed (Table 2). Each locus revealed two different size variants: 112 and 113 bp in ccmp4; 100 and 109 bp in ccmp6 and 87 and $88 \mathrm{bp}$ in ccmp10. Among the polymorphic loci, three alleles (113 in ccmp4, 100 in ccmp6 and 87 in ccmp10), with a frequency of $12.5 \%$, were found only in S. scabriflora spp. scabriflora collected in the South of Spain. Therefore, considering the eight allelic variants obtained with cPSSR markers, two different haplotypes were detected and designated herein as haplotype I and II. Haplotype II was found to be unique to S. scabriflora spp. scabriflora of Southern Spain while haplotype I was common to all subspecies, including the S. scabriflora subsp. scabriflora from Portugal.

The present results, despite the current limitation of the Silene scabriflora subspecies numbers allows investigation of Southern Spain as the biodiversity hotspot for the species from where it would have spread to the North, since Southern Spain is the only Iberian Peninsula region where the two cPSSR haplotypes are found. This region could also be considered as an $S$. scabriflora spp. scabriflora refugia, since some kind of speciation seems to have occurred in this subspecies which resulted in a new haplotype (haplotype II).

Taking into account all the molecular data obtained in the present study, S. scabriflora spp. scabriflora seems to be the ancestral of S. scabriflora. S. scabriflora spp. scabriflora represents the most widespread of S. scabriflora and shares many morphological characters with two of the other subspecies, S. scabriflora spp megacalycina and S. scabriflora spp tuberculata which is reflected by their genetic similarity. Two different SSR chlorotypes were detected within S. scabriflora spp. scabriflora corroborating the larger genetic variability compared to the remaining subspecies, all possessing a single chlorotype.

The present data provides information on the genetic diversity of S. scabriflora and phylogenetic relationships among its subspecies, which could significantly affect the long-term survival and evolution of this species.

Subspecies assignment by morphology described in Flora Ibérica was backed by the molecular results obtained in regard to genetic similarity between subspecies, suggesting some sort of isolation that probably reflects a very ancient expansion.

In this way, this study presents an efficient tool for further molecular studies in this species. The results obtained in this study provide more evidence for some proposed theories, namely; long distance dispersion, with Southern Spain as the biodiversity center of $S$. scabriflora from which this species spread to the Northern Iberian Peninsula; about speciation, Southern Spain as a refugia-within-refugia considering the speciation that occurs in S. scabriflora spp. scabriflora found in this region and the strong possibility of $S$. scabriflora spp. scabriflora being the ancestral of the species.

\section{Acknowledgments}

This work was supported by the Fundação para a Ciência e Tecnologia (FCT) SFRH/BD/43167/2008 (to J.R.) and SFRH/BD/ $96400 / 2013$ (to V.F.) grants.

\section{References}

Arroyo, J., 1997. Plant divestity in the region of the strait of Gibraltar: a multilevel approach. Lagascalia 19, $393-404$.

Bellucci, E., Nanni, L., Bitocchi, E., Rossi, M., Papa, R., 2011. Genetic diversity and geographic differentiation in the alternative legume Tripodion tetraphyllum (L.) Fourr. in North African populations. Plant Biol. 13, 381-390. http://dx.doi.org/10.1111/j.1438-8677.2010.00370.x. Bennett, K.D., 1996. Evolution and Ecology. The Pace of Life. Cambridge University Press, Cambridge. UK.

Bernasconi, G., Antonovics, J., Biere, a, Charlesworth, D., Delph, L.F., Filatov, D., Giraud, T., Hood, M.E., Marais, G.A.B., McCauley, D., Pannell, J.R., Shykoff, J. a, Vyskot, B., Wolfe, L.M., Widmer, a, 2009. Silene as a model system in ecology and evolution. Heredity 103, 5-14. http://dx.doi.org/10.1038/hdy.2009.34. Bratteler, M., Baltisberger, M., Widmer, A., 2006. QTL analysis of intraspecific differences between two Silene vulgaris ecotypes. Ann. Bot. 98, 411-419. http:// dx.doi.org/10.1093/aob/mcl113. 
Comes, H.P., Kadereit, J.W., 1998. The effect of quaternary climatic changes on plant distribution and evolution. Trends Plant Sci. 3, 432-438. http://dx.doi. org/10.1016/S1360-1385(98)01327-2.

Coutinho, J.P., Carvalho, A., Lima-Brito, J., 2014. Genetic diversity assessment and estimation of phylogenetic relationships among 26 Fagaceae species using ISSRs. Biochem. Syst. Ecol. 54, 247-256. http://dx.doi.org/10.1016/j.bse.2014.02.012.

Doadrio, I., 1988. Delimitation of areas in the Iberian Peninsula on the basis of fresh water fishes. Bonner Zool. Beitr. 39, $113-128$.

Dynesius, M., Jansson, R., 2000. Evolutionary consequences of changes in species' geographical distributions driven by Milankovitch climate oscillations. Proc. Natl. Acad. Sci. USA 97, 9115-9120. http://dx.doi.org/10.1073/pnas.97.16.9115.

Ferreira, V., Matos, M., Correia, S., Martins, N., Gonçalves, S., Romano, A., Pinto-Carnide, O., 2013. Genetic diversity of two endemic and endangered Plantago species. Biochem. Syst. Ecol. 51, 37-44. http://dx.doi.org/10.1016/j.bse.2013.08.003.

Garcia-Barros, E., Gurrea, P., Lucianez, M.J., Cano, J.M., Munguira, M.L., Moreno, J.C., Sainz, H., Sanz, M.J., Simon, J.C., 2002. Parsimony analysis of endemicity and its application to animal and plant geographical distributions in the Ibero-Balearic region (western Mediterranean). J. Biogeogr. 29, 109-124. http:// dx.doi.org/10.1046/j.1365-2699.2002.00653.x.

Gómez-Campo, C., BermúDez-de-Castro, L., Cagiga, M.J., Sánchez-Yélamo, M.D., 1984. Endemism in the Iberian Peninsula and Balearic Islands. Webbia 38, 709-714. http://dx.doi.org/10.1080/00837792.1984.10670341.

Halldén, C., Nilsson, N.O., Rading, I.M., Säll, T., 1994. Evaluation of RFLP and RAPD markers in a comparison of Brassica napus breeding lines. Theor. Appl. Genet. 88, 123-128. http://dx.doi.org/10.1007/BF00222404.

Hewitt, G., 1999. Post-glacial re-colonization of European biota. Biol. J. Linn. Soc. 68, 87-112. http://dx.doi.org/10.1111/j.1095-8312.1999.tb01160.x.

Hewitt, G., 2000. The genetic legacy of the quaternary ice ages. Nature 405, 907-913. http://dx.doi.org/10.1038/35016000.

Laurentin, H., 2009. Data analysis for molecular characterization of plant genetic resources. Genet. Resour. Crop Evol. 56, 277-292. http://dx.doi.org/10. $1007 /$ s10722-008-9397-8.

Lewontin, R.C., 1972. The apportionment of human diversity. Evol. Biol. 6, 381-398.

Mao, L.-H., Fang, Y.-M., 2014. ISSR primer screening and preliminary evaluation of genetic diversity in Haplocladium microphyllum. Biochem. Syst. Ecol. 55, 107-111. http://dx.doi.org/10.1016/j.bse.2014.02.021.

Medail, F., Quezel, P., 1997. Hot-spots analysis for conservation of plant biodiversity in the Mediterranean Basin. Ann. Mo. Bot. Gard. 84, $112-127$.

Moreno Saiz, J.C., Castro Parga, I., Sainz Ollero, H., 1998. Numerical analyses of distributions of Iberian and Balearic endemic monocotyledons. J. Biogeogr. 25, 179-194. http://dx.doi.org/10.1046/j.1365-2699.1998.251118.x.

Nei, M., 1973. Analysis of gene diversity in subdivided populations. Proc. Natl. Acad. Sci. USA 70, 3321-3323. http://dx.doi.org/10.1073/pnas.70.12.3321.

Powell, W., Morgante, M., Andre, C., Hanafey, M., Vogel, J., Tingey, S., Rafalski, A., 1996. The comparison of RFLP, RAPD, AFLP and SSR (microsatellite) markers for germplasm analysis. Mol. Breed. 2, 225-238. http://dx.doi.org/10.1007/bf00564200.

Pujol, B., Wilson, A.J., Ross, R.I.C., Pannell, J.R., 2008. Are Q(ST)-F(ST) comparisons for natural populations meaningful? Mol. Ecol. 17, 4782-4785. http://dx. doi.org/10.1111/j.1365-294X.2008.03958.x.

Ribera, I., 2000. Biogeography and conservation of Iberian water beetles. Biol. Conserv. 92, 131-150. http://dx.doi.org/10.1016/S0006-3207(99)00048-8.

Rodríguez-Sánchez, F., Pérez-Barrales, R., Ojeda, F., Vargas, P., Arroyo, J., 2008. The Strait of Gibraltar as a melting pot for plant biodiversity. Quat. Sci. Rev. 27, 2100-2117. http://dx.doi.org/10.1016/j.quascirev.2008.08.006.

Rohlf, F.J., 2008. NTSYSpc: Numerical Taxonomy System, Ver. 2.20.

Talavera, S., 1991. Silene L. In: Castroviejo, S., Aedo, C., Laínz, M., Muñoz Garmendia, F., Nieto Feliner, G., Paiva, J., Benedí, C. (Eds.), Flora Iberica 2. Real Jardín Botánico. CSIC, Madrid, pp. 313-406.

Trindade, H., Sena, I., Gonçalves, S., Romano, A., 2012. Genetic diversity of wild populations of Tuberaria major (Cistaceae), an endangered species endemic to the Algarve region (Portugal), using ISSR markers. Biochem. Syst. Ecol. 45, 49-56. http://dx.doi.org/10.1016/j.bse.2012.06.028.

Wang, F.-Y., Ge, X.-J., Gong, X., Hu, C.-M., Hao, G., 2008. Strong genetic differentiation of Primula sikkimensis in the East Himalaya-Hengduan Mountains. Biochem. Genet. 46, 75-87. http://dx.doi.org/10.1007/s10528-007-9131-9.

Wang, Y., Jiang, H., Peng, S., Korpelainen, H., 2011. Genetic structure in fragmented populations of Hippophae rhamnoides ssp. sinensis in China investigated by ISSR and cpSSR markers. Plant Syst. Evol. 295, 97-107. http://dx.doi.org/10.1007/s00606-011-0466-7.

Weising, K., Gardner, R.C., 1999. A set of conserved PCR primers for the analysis of simple sequence repeat polymorphisms in chloroplast genomes of dicotyledonous angiosperms. Genome 42, 9-19.

Whitlock, M.C., 2008. Evolutionary inference from QST. Mol. Ecol. 17, 1885-1896. http://dx.doi.org/10.1111/j.1365-294X.2008.03712.x.

Yeh, F., Yang, R.C., Boyle, T., 2000. POPGEN (Version 1.32), Microsoft Windows-based Freeware for Population Genetic Analysis.

Zhao, L., Liu, H., Cai, G., Xia, M., 2014. Assessment of the genetic diversity and genetic relationships of Lilium in China using ISSR markers. Biochem. Syst. Ecol. 55, 184-189. http://dx.doi.org/10.1016/j.bse.2014.03.024.

Zietkiewicz, E., Rafalski, A., Labuda, D., 1994. Genome fingerprinting by simple sequence repeat (SSR)-anchored polymerase chain reaction amplification. Genomics 20, 176-183. http://dx.doi.org/10.1006/geno.1994.1151. 